\title{
Öğretmenlerin Bu Benim Eserim Proje Yarışması Rehberlik Sürecine İlişkin Görüşleri*
}

\author{
Ayşe OĞUZ ÜNVER \\ Muğla Sitkı Koçman Üniversitesi Eğitim Fakültesi \\ E-mail: ayseoguz@mu.edu.tr \\ Sertaç ARABACIOĞLU \\ Muğla Sttkı Koçman Üniversitesi Eğitim Fakültesi \\ E-mail: sertacarabacioglu@mu.edu.tr \\ Hasan Zühtü OKULU \\ Muğla Sttkı Koçman Üniversitesi Eğitim Fakültesi \\ E-mail: hasanokulu@mu.edu.tr
}

\begin{abstract}
$\ddot{O} z$ et
Bu Benim Eserim [BBE] proje başvurulart incelendiğinde, başvuruların ciddi bir düşüşs eğiliminde olduğu gözlenmektedir. Bu durumun pek çok nedeni olabilir. Mevcut araştırmada, bu nedenlerden önemli olarak görülen öğretmenlerin, BBE proje yarısmasına rehberlik sürecine yaklaşımları, karşılaş̧tıkları zorluklar ve katılımlarına engel durumların incelenmesi amaçlanmıı̧tır. Durum çalı̧̧ması olarak yürütülen araştırmaya bir Batı Anadolu İlinde çalışmakta olan 65 fen bilimleri ve ilköğretim matematik öğretmenleri (44 kadın ve 21 erkekten) gönüllü katılmışlardır. Veri toplama aracı demografik özellikler ve açık uçlu sorularla oluşturulmuş ve elde edilen veriler betimsel içerik analizi kullanılarak NVivo 10 programında çözümlenmiştir. Sonuç olarak, öğretmenlerin BBE proje yarışmalarına katılımında karşılaştıkları zorlukları veya katılımına engel durumları "eğitim beklentisi, bireysel, maddi, zaman, sınıf ortamı, öğrenci, ögrenci velisi, okul yönetimi, illilçe milli eğitim müdürlü̆̈̈̈ ve karşılaş̧tıkları diğer sorunlar" olmak üzere temel başlıklarda tartı̧̧ılmuştır.
\end{abstract}

Anahtar Kelimeler: Bu Benim Eserim (BBE) proje yarışmasl, fen bilimleri ve ilköğretim matematik öğretmenleri, bilimsel süreç, durum çalışması.

\section{Teachers' Thoughts about The Guidance Process of 'This is My Work Project Competition'}

\begin{abstract}
When "This is My Work Science and Mathematics Project Study for Elementary School Students (TMW)" competition applications were examined, it is observed that the applications were tendency to decrease in a serious way. This situation may have several reasons. In this research it is assumed that one of the main reasons of teacher's approaches to guidance process of TMW's competition; the challenges and situations faced obstacles is aimed to investigate. The case study conducted with 65 voluntary science and primary mathematics teachers (44 female and 21 male) in one of the Western Anatolian province. The data collection tool consists of demographics variables and open-ended questions and the obtained data were analyzed by using descriptive content analysis via NVivo 10. As a result, teacher's challenges and situations faced obstacles to TMW project participation were discussed with basic topics as educational aspirations, personal, financial, time, classroom environment, students, parents, school administration, provincial/district national education directorate and the other encountered problems.
\end{abstract}

\footnotetext{
* Bu araştırmada elde edilen bulguların bir bölümü 12-14 Kasım 2015 tarihleri arasından düzenlenen "Felsefe, Eğitim ve Bilim Tarihi”
} adlı sempozyumda sözlü bildiri olarak sunulmuștur. 
Keywords: This is my work (TMW) project competition, science and primary mathematics teachers, scientific process, case study.

\section{Giriş}

Ders dışı eğitim çalışmaları kapsamında değerlendirilen proje yarışmaları ve bu amaçla hazırlanan ürünlerden oluşan bilim fuarları dünyada ve buna paralel olarak Türkiye'de temel bilimlere yönelik farkındalık ve ilgiyi arttırma amacında giderek önem kazanmaktadır. Proje yarışmalarının çıkış noktasında bilimsel ve teknik anlamda donanımlı bireylerin geliştirilmesi, bilim ve matematiğe karşı toplumda ilginin oluşturulması, öğretmen ve öğrenciler arasında fikirlerin paylaşılması, bilimin toplum ile buluşturulması, ve özgün fikirlerin ekonomiye kazandırılması düşünceleri yer almaktadır (UNESCO, 1956). Bu yarışmaların ilk örnekleri 1920'li yıllarda Amerika Bileşik Devletleri'nde Edward W. Scripps ve William Emerson Ritter tarafindan kurulan Society for Science the Public (SSP) (https://www.societyforscience.org/) isimli organizasyonun çalışmaları ile başlamıştır. 1942 yılında The Science Talent Search (Bilim Yeteneklisini Arama) adıyla ilk bilim yarışmasını/fuarını düzenleyen topluluk, günümüzdeki proje yarışmalarına da bu anlamda öncülük etmektedir. Fuar uzun yıllar SSP ve Westinghouse Electric Corporation iş birliğiyle Westinghouse Science Talent Search adıyla devam etmiş, günümüzde ise SSP ve Intel iş birliği sonrasında Intel International Science and Engineering Fair (Intel ISEF) adını almıştır. Intel ISEF 75 ülkeden yerel, bölgesel ve ulusal düzeydeki yarışma ağlarında projeleri değerlendirilerek, kazanan projeler içerisinden her yıl 1,700 projenin yarıştığı ve kazananlara 4 Milyon Dolar ödülün dağıtıldığı uluslararası bir proje yarışmasına dönüşmüştür (SSP, 2015). Proje yarışmalarına olan ilgi, gerek eğitimdeki yönelimler gerekse pek çok büyük şirketin maddi desteği sonucunda giderek artmaktadır. Özellikle öğrencilerin Bilim, Teknoloji, Mühendislik ve Matematik (Science, Technology, Engineering and Mathematics-STEM) alanlarından birinde başarılı bir kariyer yapması için gereken becerilere sahip olmalarını destekleyen günümüzün bilim eğitimi anlayışı proje yarışmaları ile oldukça bütünleşmektedir (NIA, 2010). Tablo. 1'de uluslararası düzeyde farklı organizasyonlarca desteklenen ve çeşitli alanlarda gerçekleştirilen proje yarışmalarından bazıları sunulmuştur.

Tablo 1. Uluslararası proje yarışmalarından örnekler

\begin{tabular}{|c|c|}
\hline Yarışmanın adı & Web adresi \\
\hline International Science and Engineering Fair & $\begin{array}{l}\text { https://student.societyforscience.org/intel- } \\
\text { isefhttps://student.societyforscience.org/intel-isef }\end{array}$ \\
\hline New York Hall of Science (NYSCI) & http://nysci.org/http://nysci.org/ \\
\hline World Maker Faire & http://makerfaire.com/http://makerfaire.com/ \\
\hline Google Science Fair & $\begin{array}{l}\text { https://www.googlesciencefair.com/en/https://www.googlescie } \\
\text { ncefair.com/en/ }\end{array}$ \\
\hline LEGO Education & $\begin{array}{l}\underline{\text { https://education.lego.com/en- }} \\
\underline{\text { us/lesi/competitionshttps://education.lego.com/en- }} \\
\underline{\text { us/lesi/competitions }}\end{array}$ \\
\hline NASA Engineering Design Challenge & $\begin{array}{l}\text { http://www.nasarealworldinworld.org/Home.aspxhttp://www.n } \\
\text { asarealworldinworld.org/Home.aspx }\end{array}$ \\
\hline
\end{tabular}




\subsection{Bu Benim Eserim Proje Yarışması}

http://www.nasa.gov/roverchallenge/home/index.html

Uluslararası alandaki gelişmelere paralel olarak Türkiye'de de pek çok bilim temelli proje yarışması ve özellikle TUBİTAK destekli bilim fuarları düzenlenmektedir. $\mathrm{Bu}$ çalışmaların içerisinde Milli Eğitim Bakanlığı Temel Eğitim Genel Müdürlüğü tarafından düzenlenen $\mathrm{Bu}$ Benim Eserim (BBE) Proje Yarışması Türkiye'de ki tüm ortaokul öğrencilerinin katılımına açık olması açısından oldukça önemli bir yere sahiptir. Yarışma aşamalı süreçlerle çok sayıda projeye yarışma imkanı sunabilmesi yönüyle ülke genelinde en yaygın katılımcı kitlesine sahiptir. BBE proje yarışmasının temel amacı, ülke genelinde yetenekli çocuklara sahip çıkma, geleceğin bilim insanlarını keşfedip, var olan yeteneklerini geliştirme, onlara gerekli desteği vererek araştırmacı bir ruh kazandırma ve bilimi toplumda yaygınlaştırarak teşvik etmektir (TGEM, 2014, s.4). Resmi ve özel ortaokulların $5,6,7$ ve 8 . sınıf öğrencilerine yönelik matematik ve fen bilimleri alanlarında projelerin yarıştığı proje yarışmasında öğrencilerin yaratıcı düşünme becerileri, bilimsel yöntemleri kullanma yetenekleri, ilgili konu alanına ait yeterlilikleri ve kendilerini ifade edebilme düzeyleri değerlendirilirken, projeler ise tutarlılık, alana katkı, ekonomiklik, sosyal ve akademik yarar, uygulanabilirlik ve kullanışlılık yönleri bakımından değerlendirilmektedir (TGEM, 2014, s.18).

Proje yarışmaları öğrencileri pek çok yönden teşvik edebilmektedir. Örneğin; proje yarışmaları öğrencileri (i) bilim fuarlarına toplum tarafından gösterilen ilgi, (ii) öz yeterlilik algısı, (iii) fikirlerinin kabul görmesine ilişkin haz duyma, başarı duygusu ya da ödüllendirme, (iv) seyahat, toplantı, bilgi paylaşım imkânlarının sunulması ve son olarak (v) öğrenme stratejisi geliştirme yönleriyle motive etmektedir (Dionne, Reis, Trudel, Guillet, Kleine, ve Hancianu, 2011). Bu nedenle proje hazırlama sürecinde öğrenciye danışmanlık yapacak öğretmenin projelere yaklaşımı oldukça önemlidir. BBE projelerinde danışmanlık yapacak öğretmenler için gönüllülük esas alınmasına karşın, danışmanlığı üstlenen bir öğretmen için birtakım yükümlülükler bulunmaktadır. Örneğin; proje hazırlamaya istekli bir öğrenci bir danışman öğretmen seçmekte ve o öğretmen en fazla üç öğrenciye danışmanlık yapabilmektedir. Belirli alanlarda yoğunluğun olacağı düşünülerek öğrencinin proje hazırlamak istediği branşta okul içerisinde gönüllü öğretmen bulunamaması durumunda farklı branş öğretmenlerin de danışmanlık yapabilmesine imkan tanınmıştır (TGEM, 2014, s.5).

\subsection{Proje yarışmalarına ilişkin yapılan değerlendirmeler}

Proje yarışmaları ve bu amaçla ortaya çıkan proje ürünlerinin sergilendiği bilim fuarlarına ilişkin alan yazında pek çok araştırma mevcuttur. Ders dışı etkinlikler kapsamında değerlendirilebilecek bu faaliyetler öğrencileri pek çok yönden bilim ile buluşturabilmektedir. Bruce ve Bruce (2000)'a göre bilim temelli gerçekleştirilen proje yarışmaları öğrencileri bilime teşvik etme ve bilime karşı olumlu tutum geliştirmede oldukça önemli bir yere sahiptir. Öğrencilerin bilimsel proje yarışmalarına katılmaları yalnızca yeni şeyler öğrenmeleri açısından değil aynı zamanda mevcut bilgilerini nasıl kullanacaklarını öğrenmeleri ve sahip oldukları bilgileri deneyimlenerek geliştirmeleri açısından önemlidir (Balas, 2003).

Öğrencilerin bilim temelli projelerini sergiledikleri proje yarışmalarında öğrencilere rehberlik yapan öğretmenlerin görüşleri, bu yarışmalarının niteliğini ve bilim eğitimine 
katkısını ortaya koymak açısından önemlidir (Tortop, 2013). İlgili literatür incelendiğinde öğretmenlerin, öğretmen adaylarının ve öğretmen eğitimcilerinin bilim yarışmalarına ve bilim fuarlarına yönelik düşüncelerinin araştıııldığ (Grote, 1995a; Grote, 1995b; Bunderson ve Anderson, 1996; Schneider ve Lumpe, 1996; Windschitl, 2003; Tortop, 2013; Tortop, 2014)

Bu çalışmalardan bazılarına yakından bakılacak olursa örneğin, Schneider ve Lumpe (1996), araştırmalarında bilim yarışmalarının eğitim programının kazanımlarıyla ne kadar örtüştüğünü incelemişlerdir. Araştırma sonucunda öğretmenlerin bilim yarışmalarının fen konularının öğretilmesinde oldukça etkili olduğu ve proje sürecinde gerçekleştirilen etkinliklerin aktif katılımlı bilime (hands-on / minds-on science) teşvik etmesi nedeniyle fen bilimleri programının hedeflerine ulaşmasında etkili olduğu ortaya konulmuştur. Ayrıca öğretmenler, bilimsel projeler ile öğrencilerin gerçek dünyayı keşfetme yoluyla bilimsel sorgulama ve üst düzey düşünme becerilerini geliştirebileceklerini ifade etmişlerdir.

Bunderson ve Anderson (1996), 340 öğretmen adaylyla gerçekleştirdikleri çalışmalarında katılımcıların büyük çoğunluğunun, proje yarışmalarının öğrenciler için oldukça yararlı olduğu düşüncesine sahip olduklarını belirlemişlerdir. Ayrıca araştırma sonunda, öğretmen ve öğrenci ebeveynlerinin desteğinin proje yarışmaları için oldukça önemli olduğunu, özellikle ebeveynlerin desteğinin aile içi iletişimi de geliştireceği sonucuna ulaşılmıştır. Bunların yanı sıra projelerin değerlendirilirken alternatif değerlendirme yaklaşımlarına da yer verilmesi, gerçekleştirilen bilim yarışmalarında öğrencilerin gönüllülük esasına göre seçilmeleri gerektiği vurgulanmıştır. Grote (1995b), öğretmenlerin bilimsel projeler ve bilim fuarları ile ilgili görüşlerini araştırmıştır. Araştırma sonucunda öğretmenlerin bilimsel proje yarışmalarının, öğrencileri bilime karşı heveslendirdiği, iletişim becerilerini geliştirmeye yönelik fırsatlar sağladığı ve bilimle ilgilenen diğer öğrencilerle etkileşime girme olanağı tanıdığını düşündükleri sonuçlarına ulaşmıştır. Ayrıca katılımcılar öğretmen eğitiminde bir araştırma projesinin nasıl hazırlayabileceklerini öğrenmek istediklerini belirtmişlerdir. Buna ek olarak proje yarışmaları bilim eğitiminde çok önemli bir yere sahiptir. Öğretmenlerin çok büyük bir çoğunluğu bu tip yarışmaların öğrencilere bilimsel yöntemlerin öğretilmesinde oldukça etkili olduğunu vurgulamaktadır. Dahası öğrencilerin bilimsel araştırma projesi ile öğrendiği konuları sınıf içerisinde tekrar öğretilmesinin yararlı olacağını belirtmektedirler. İlkokul düzeyindeki öğrencilerin hazırladıkları projeleri sunmaları erken yaşlarda özgüven gelişimi için önemli olduğu yönünde görüşler olmasına karşın, bağımsız araştırma projelerinin lise düzeyindeki öğrenciler için daha uygun olduğu da belirtilmiştir.

Grote (1995a) ise araştırmasında öğretmen eğitimcilerinin bilim fuarlarına ve bilim yarışmalarına yönelik görüşlerini incelemiştir. Araştırmanın öne çıkan bulguları arasında, bilim yarışmalarının hem okullarda hem de öğretmen yetiştiren kurumlarda öğretim programları içerisine dahil edilmesi gerektiği yer almaktadır. Buna ek olarak, katılımcılar, bilim yarışmalarının okul dersleri kadar faydalı olabileceğini belirtmiş, özellikle bağımsız gerçekleştirilen projelerin bilginin yapılandırılmasında etkili olabileceğini vurgulamışlardır. Ayrıca, öğretmen eğitimciler, öğretmenlerin bilimsel proje hazırlama sürecindeki rollerini tam olarak kavramada sıkıntı yaşadıklarını belirtmişlerdir. Alan yazında proje hazırlama sürecinde öğretmenin rolü rehberlik olarak ifade edilmektedir. Öğretmen öğrenciye "gündelik" yaşamındaki soruları araştırılabilecek sorulara dönüştürme, test edilebilir sorular geliştirme, proje sorularını seçme, soruya cevap verebilecek veri toplama yöntemlerini seçme, verileri analiz ve görselleştirmede belirli bir çerçeve oluşturma gibi pek çok konuda rehberlik yapabilmektedir (Windschitl, 2003). Tortop (2013), "Bu Benim Eserim Proje Yarışması" na katılan öğretmenlerle 
gerçekleştirdiği görüşmeler sonucunda, öğrencilerin proje konusu bulmakta zorlandıkları ve projelerin çoğunlukla öğretmenler veya öğrencilerin ebeveynleri tarafından gerçekleştirildiği sonuçlarına ulaşmıştır. Ayrıca öğretmenlerin rehberlik konusunda yeterli düzeye sahip olmadıklarını ve öğrenci ebeveynlerinin bilim yarışmalarına karşı olumsuz görüş sergilediklerini belirtmiş̧tir. Tortop (2014), diğer bir araştırmasında öğretmen adaylarının bilimsel projeleri nasıl değerlendirdiklerini incelemiştir. Bu amaçla proje tabanlı öğretime yönelik eğitim alan öğretmen adaylarına 30 adet öğrenci projesi vermiş ve her birinin bu projeleri bir rubriğe göre değerlendirmelerini istemiştir. Araştırmada, öğretmen adaylarının projeleri değerlendirirken en az kullanılan bilimsel yönteme, en çok ise projenin ekonomik ve sosyal yararlığına dikkat ettikleri sonucuna ulaşılmıştır.

İlgili literatür genel olarak değerlendirildiğinde araştırmalarda bilimsel proje yarışmalarının ve bilim fuarlarının öğrencilerin, bilimsel sorgulama becerilerini geliştirdiği, bilimsel yöntemleri kullanmada etkili olduğu, bilime karşı ilgi oluşturmada ve bilim ile ilgili kariyer seçimine destek sağladığı belirlenmiştir (Bunderson ve Anderson, 1996; Fisanick, 2010; Dionne, Reis, Trudel, Guillet, Kleine, ve Hancianu, 2012). Ancak, öğretmenlerin rehberlik kavramını tam olarak kavrayamadıkları, öğrenciyi teşvik etmede ve yönlendirmede yeteri kadar başarılı olamadıkları gibi sonuçlara rastlanılmaktadır (Tortop, 2013). Bu bağlamda, öğretmenlerin proje sürecinde karşılaştıkları durumların belirlenmesi, proje hazırlama sürecine öğretmenlerin gözünden bakılması açısından önem taşımaktadır.

\subsection{Problem durumu}

Gün geçtikçe proje yarışmalarına yönelik teşviklerin artmasına karşın proje yarışmalarına katılımlarda azalmalar görülebilmektedir. Bu durumun proje yarışma sayılarının artışı, proje yarışmalarına ayrılan bütçelerin kısıtlanması ve proje yarışma sürecinin zaman açısından dar olması gibi pek çok nedeni olabilir. Türkiye'de 2012-2015 yılları arasında $\mathrm{Bu}$ Benim Eserim Proje Yarışmalarına ilişkin proje başvuru istatistikleri Tablo 2.'de sunulmuştur.

Tablo 2. 2012-2015 yılları arasındaki BBE proje yarışması başvuru istatistikleri

\begin{tabular}{|c|c|c|c|}
\hline Proje başvuru yılı & $\begin{array}{l}\text { Türkiye geneli } \\
\text { başvuru sayısı* }\end{array}$ & Bölgede sergilenen & $\begin{array}{c}\text { Ankara final sergisine } \\
\text { kalan }\end{array}$ \\
\hline $2012-2013$ y1lı & 78,887 & 968 & $100(66$ fen +34 mat $)$ \\
\hline $2013-2014$ yılı & 42,494 & 941 & $100(68$ fen +32 mat $)$ \\
\hline $2014-2015$ y1li & 26,725 & $* *$ & $* *$ \\
\hline \multicolumn{4}{|c|}{$\begin{array}{l}\text { * Veriler MEB TEGM tarafından hazırlanan BBE proje kataloglarında yer alan bilgilerden derlenmişti } \\
\text { (http://tegm.meb.gov.tr/bubenimeserim/katalog.html). } \\
\text { ** Araştırmanın gerçekleştirildiği dönemde } 2014-2015 \text { bölge sergi ve Ankara final sergi sonuçları açıklanmamıştır }\end{array}$} \\
\hline
\end{tabular}

Türkiye'nin gelecekteki bilimsel kültürü ve bu kültürün niteliğinin gelişimi açısından öğrencileri BBE proje yarışması ya da benzeri yarışmalara katılımın arttırılması oldukça önemlidir. Buna karşın son yıllarda BBE proje başvuruları incelendiğinde, başvuruların ciddi bir düşüş eğiliminde olduğu gözlenmektedir. Artışın sağlanabilmesi için proje yarışmalarına olan ilginin azalma nedenlerinin araştırılması gerekmektedir. Bu durumun pek çok nedeni olabilir. Mevcut araştırmada, bu nedenlerden önemli olarak görülen; öğretmenlerin BBE proje yarışmasına rehberlik sürecine yaklaşımları, karşılaştıkları zorluklar ve katılımlarına engel durumların incelenmesi amaçlanmıştır. 


\section{Araştırmanın yöntemi}

Çalışma amacı doğrultusunda nitel araştırma türlerinden durum çalışması olarak tasarlanmıştır. Bu türde desenlenen araştırmalarda duruma ilişkin unsurlar bütüncül bir yaklaşımla incelenebilir ve ilgili durumdan nasıl etkilendikleri araştırılabilir (Yıldırım ve Şimşek, 2013). Dolayısıyla bu çalışmada; öğretmenlerin BBE proje yarışmalarındaki rehberlik sürecine yaklaşımları, karşılaştıkları zorluklar ve katılımlarına engel durumların bütüncül bir yaklaşımla incelenmesi ve bu durumdan nasıl etkilendiklerinin araştırılması hedeflenmiştir.

\subsection{Araştırmanın katılımcıları}

Araştırmanın katılımcılarını bir Batı Anadolu ilinde çalışmakta olan 44 kadın ve 21 erkekten oluşan toplamda 65 fen bilimleri ve matematik öğretmeni oluşturmaktadır. Örneklem seçiminde amaçlı örnekleme yöntemlerinden kolay ulaşılabilir durum örneklemesi kullanılmıştır. Katılımcıların 20'si matematik, 45'i fen bilimleri öğretmenidir. Ayrıca öğretmenlerin mesleki tecrübeleri 1 yıl ile 24 yıl arasında değişmekte ve ortalama 9.9 yıldır. Öğretmenlerin 27'si merkeze uzak ilçe ve köy okullarında 38'i ise il merkezindeki okullarda görev yapmaktadır. Lisansüstü eğitim öğrenciye bilimsel araştırma yaparak bilgilere erişme, bilgiyi değerlendirme ve yorumlama yeteneğini kazandırmayı amaçlamaktadır. $\mathrm{Bu}$ nedenle $\mathrm{BBE}$ proje yarışması için öğretmen yeterliliklerinin değerlendirilmesinde önemli bir değişken olduğu düşünülmektedir. Katılımcı grubunda yer alan öğretmenlerin 13'ü lisansüstü eğitimini tamamlamıştır. Buna ek olarak öğretmenlerden 21 'i proje hazırlama eğitimi almıştır. $\mathrm{Bu}$ veriler 1şığında katılımcı grubunun BBE proje yarışmalarındaki proje tecrübeleri ve hazırlanan projelerin başarı durumları (İl, Bölge ve Final Sergisi) Şekil 1.'de sunulmuştur.

Şekil 1. Katılımcıların BBE proje yarışması tecrübelerinin proje başarısına göre dağılımı

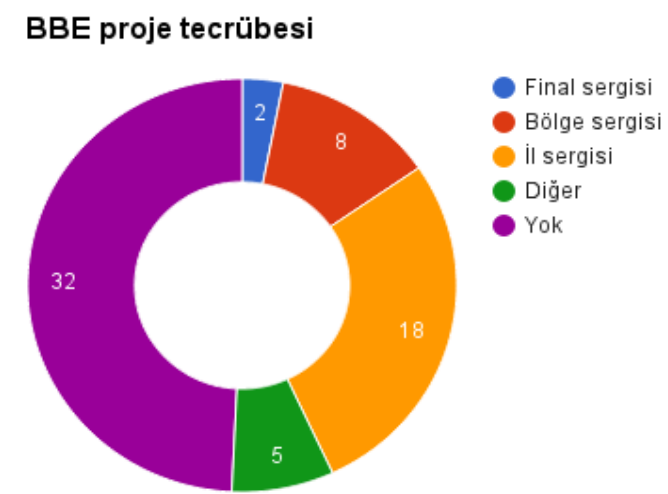

Şekil 1.'de yer alan katılımcıların proje deneyimleri incelendiğinde 33 öğretmenin BBE proje yarışmalarına proje hazırladığı, bu projelerden 2'sinin final, 8'inin bölge, 18'inin il sergilerine ulaştığı, buna karşın 5 öğretmenin hazırladıkları projeleri çeşitli gerekçelerle yarışmalara gönderemedikleri belirlenmiştir. Yukarıda belirtildiği üzere, BBE Proje Yarışmasına proje hazırlayan 33 katılımcının lisansüstü/proje eğitimi almış olma durumları Şekil 2.' de sunulmuştur.

Şekil 2. BBE proje tecrübesine sahip 33 katılımcının lisansüstü/proje eğitimi almış olma durumları 


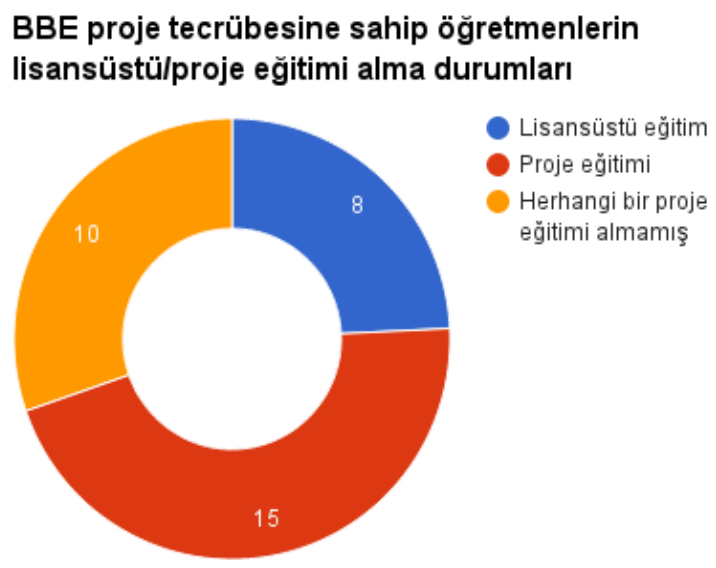

Şekil 2.'de yer alan BBE proje yarışmalarına proje hazırlamış 33 öğretmenin lisansüstü/proje eğitimi alma durumları incelendiğinde 8 öğretmenin lisansüstü araştırma deneyimine sahip olduğu, 15 öğretmenin ise proje eğitimi almış olduğu görülmektedir.

\subsection{Veri toplama aracl}

Öğretmenlerin BBE proje yarışmalarına proje hazırlarken karşılaştıkları zorlukları ve katılımlarına engel durumları belirlemek amacıyla açık uçlu sorulardan oluşan bir veri toplama aracı geliştirilmiştir (Ek-1). Veri toplama aracının geliştirilme sürecinde literatürde yer alan ve öğretmenlerin müfredat dışı etkinliklerde karşılaştırdıkları güçlükler ve güçlüklerin kaynaklarını inceleyen araştırmalar incelenmiş ve bir soru havuzu hazırlanmıștır. Öğretmen eğitiminde uzman iki akademisyen ve alanında 10 yıl tecrübeye sahip bir öğretmenden uzman görüşleri alınarak veri toplama aracının ilk şekli oluşturulmuştur. Sonrasında veri toplama aracı beş fen bilimleri öğretmenine uygulanmıştır. Pilot çalışma sonrasında öğretmenlerin yöneltilen soruların dişında farklı düşüncelerini de belirtmek istedikleri görülerek "diğer" başlığ 1 altında bilgi verebilecekleri bir bölüm veri toplama aracına eklenmiş ve veri toplama aracına son şekli verilmiştir.

Veri toplama aracının ilk bölümünde öğretmenin deneyim, çalıştığı okul, lisan üstü öğrenim durumu, proje eğitimi alma durumu, proje tecrübesi, hazırlamış olduğu proje başlıkları ve projelerin başarı durumu değişkenlerini içeren demografik bilgilerin toplanması amaçlanmıştır. İkinci bölümde ise öğretmenlerin BBE proje yarışmaları için öğrencilere danışmanlık sürecinde karşılaştıkları zorlukları veya proje rehberliğine engelleyen durumları "eğitim beklentisi, bireysel, maddi, zaman, sınıf ortamı, öğrenci, öğrenci velisi, okul yönetimi, il/ilçe milli eğitim müdürlüğ̈̈ ve karşılaştıkları diğer sorunlar" açılarından değerlendirebilecekleri açık uçlu sorular yer almıştır.

\subsection{Verilerin analizi}

Elde edilen veriler betimsel içerik analizi kullanılarak çözümlenmiştir. Verilerin analizinde kodlama ve tema oluşturulması sürecinde NVivo 10 nitel veri analiz programı kullanılmıştır. NVivo10 programı nitel araştırma sürecinde elde edilen kapsamlı ve zengin verilerin kolaylıkla kodlanarak düzenlenmesine, ayrıca oluşturulan temalar ve kodlar arasındaki ilişkilerin anlaşılabilir bir şekilde sunulmasını sağlamaktadır (Richards, 2002). Ayrıca veriler iki farklı araştırmacı tarafından ayrı ayrı analiz edilmiş ve araştırmacılar arası uyumun ne düzeyde olduğunu belirlemek amacıyla Cramer's v değeri hesaplanmıştır. Cramer's v değeri .72 olarak bulunmuştur. Bu değerin .70 ile .100 arasında olması 
araştırmacıların analizleri arasında güçlü bir ilişkinin olduğunun göstergesidir (Cramer, 1999).

Analiz sürecinde katılımcı ifadelerinden elde edilen kodlar öncelikle serbest kodlar şeklinde hazırlanmış, daha sonra bu serbest kodlar özelliklerine bağlı olarak önceden belirlenen temalar altında gruplandırılmıştır. Temaların ve kodların daha rahat anlaşılabilmesi için frekans ve yüzde dağılımından yararlanılmıştır. Ayrıca her bir katılımcıya bir numara verilmiş ve katılımeı ifadeleri sunulurken bu numaradan faydalanılmıştır.

\section{Bulgular}

BBE proje yarışmalarında öğretmenlerin projeye rehberlik sırasında karşılaştıkları zorluklar ve katılımı engelleyen durumların değerlendirildiği araştırmada, ilk olarak öğretmenlerin bu alanda hazırlanacak bir eğitimden beklentileri sorgulanmıştır. Öğretmenlerin eğitim beklentilerine ilişkin bulguları Tablo 3.'de sunulmuştur.

Tablo 3. Öğretmenlerin BBE proje yarışmalarına yönelik eğitim beklentileri

\begin{tabular}{|c|c|c|c|}
\hline Tema & Kod & f & $\%$ \\
\hline \multirow{4}{*}{ Proje bilgisi } & Proje nedir? Öğrenmek & 2 & 1,7 \\
\hline & Bilimsel araştırma yöntemlerini öğrenme & 3 & 2,5 \\
\hline & Örnek projelerle öğrenmek & 5 & 4,2 \\
\hline & Proje hazırlamayı öğrenmek & 58 & 49,1 \\
\hline \multirow{5}{*}{ Rehberlik } & Güçlüklerle nasıl başa çıkılacağını öğrenmek & 2 & 1,7 \\
\hline & $\begin{array}{l}\text { Öğrenciyi nasıl proje hazırlamaya teşvik edeceğini } \\
\text { öğrenmek }\end{array}$ & 5 & 4,2 \\
\hline & Rehberlik yapabilme becerisi kazanmak & 16 & 13,6 \\
\hline & Öğrencilere proje becerisi kazandırmak & 6 & 5,1 \\
\hline & Öğrencilere bilimsel düşünmeyi öğretmek & 3 & 2,5 \\
\hline \multirow{5}{*}{ Beceri } & Özgüven kazanmak & 2 & 1,7 \\
\hline & Tecrübe paylaşımı & 6 & 5,1 \\
\hline & Daha iyi proje hazırlayabilmek & 2 & 1,7 \\
\hline & Bakış açısını geliştirmek & 8 & 6,8 \\
\hline & Toplam & 118 & 100 \\
\hline
\end{tabular}

Tablo 3.'de yer alan bulgular incelendiğinde, öğretmenlerin proje eğitimi almaya yönelik beklentilerinin "Proje Bilgisi", "Rehberlik" ve "Beceri" temaları altında toplandığ anlaşılmaktadır. İlgili tablo, öğretmenlerin BBE proje yarışmasına proje hazırlamada 
kendilerinde gözlemledikleri eksikliklere ve eğitim alma ihtiyacı duydukları alanlara 1şık tutmaktadır.

Katılımcıların "Proje Bilgisi" temasında, "Proje hazırlamayı ögrenme" konusunda öncelikli olarak eğitime ihtiyaç duydukları görülmektedir. Öğretmenlerin bu konuya ilişkin ifadelerinden bazıları aşağıda sunulmuştur:

K-20. Yaratıcılı̆̆ın projeye dönüştürülmesini ve projeyi nasıl amacına ulaştırabileceğini öğrenmeyi ve doğru bir şekilde proje hazırlayabilmeyi istiyorum -"Proje hazırlamayı ögrenme"

$K$-41. Bu yıl ögrencilerimle proje hazırlama işine başladım. Ama nereden başlayacağımı, hangi yollar takip edeceğimi bilmiyorum. Hala kafamdaki Matematik projesinin konseptini oluşturamadım-"Proje hazırlamayı öğrenme"

$K$-42. BBE proje yarışmasında, yazım, katılım ve sunum aşamalarında tek başıma yeterli olabilmeyi istiyorum -"Proje hazırlamayı ögrenme"

İlgili tabloya bakıldığında, Rehberlik teması altında "Öğrenciyi nasıl proje hazırlamaya teşvik edeceğini ögrenmek", "Rehberlik yapabilme becerisi kazanmak" ve "Öğrencilere proje becerisi kazandırmak” kodlarının öne çıktı̆̆ 1 gözlemlenmektedir. Öğretmenlerin bu kodlara ilişkin ifadeleri aşağıda sunulmuştur:

K-6. Öğrencileri projeye yöneltmek ve istekli hale getirebilmek için neler yapılması gerektiğini ögrenmek isterim - "Öğrenciyi nasıl proje hazırlamaya teşvik edeceğini ögrenmek"

K-31. Bilimi ögrencilerime sevdirmek ve bu yöndeki projelerde nasll yönlendirme yapabileceğimi öğrenmek istiyorum- "Rehberlik yapabilme becerisi kazanmak"

$K$-47. Öğrencilerimin bakış açısını genişletebilmeyi, sorgulama yeteneklerini, soru sorma becerilerini geliştirebilmeyi istiyorum. Merakl öğrencilerime proje hazırlama konusunda faydalı olmayı istiyorum- "Öğrencilere proje becerisi kazandırmak"

Buna ek olarak, farklı konularda Beceri'lerini geliştirme isteklerini ifade eden öğretmenlerin çoğunlukla "Tecrübe paylaşımı" ve "Bakış açısını geliştirmek" düşüncelerine sahip oldukları görülmektedir. $\mathrm{Bu}$ kodlara ilişkin ifadeler aşağıda sunulmuştur:

K-40. Okulumda yapabilecĕgim farklı projeler varsa, bunları diğer ögretmen arkadaşlardan öğrenmek, fikir almak - "Tecrübe paylaşımı"

K-21. Matematik dersinde proje üretmede sikıntılar yaşlyorum, bu nedenle farklı bakış açıları edinmek istiyorum - "Bakış açısını geliştirmek"

Öğretmenlerin bireysel anlamda proje yarışmalarına yaklaşımları projelerin üretiminden, yarışma sürecinin sonuna kadar oldukça önem taşımaktadır. Bu nedenle araştırmanın katılımcı grubundaki öğretmenlerin bireysel anlamda karşılaştıkları zorluklar ve katılımlarına engel durumlar değerlendirilmiş ve Tablo. 4'de sunulmuştur.

Tablo 4. Öğretmenlerin BBE proje yarışmalarında karşılaştığı “bireysel” zorluklar ve katılımlarına engel durumlar

\section{Tema}

Kod
$\%$ 
MSKU Eğitim Fakültesi Dergisi MSKU Journal of Education

ISSN 2148-6999 Cilt-Volume 2, Sayl-Number 2, 2015

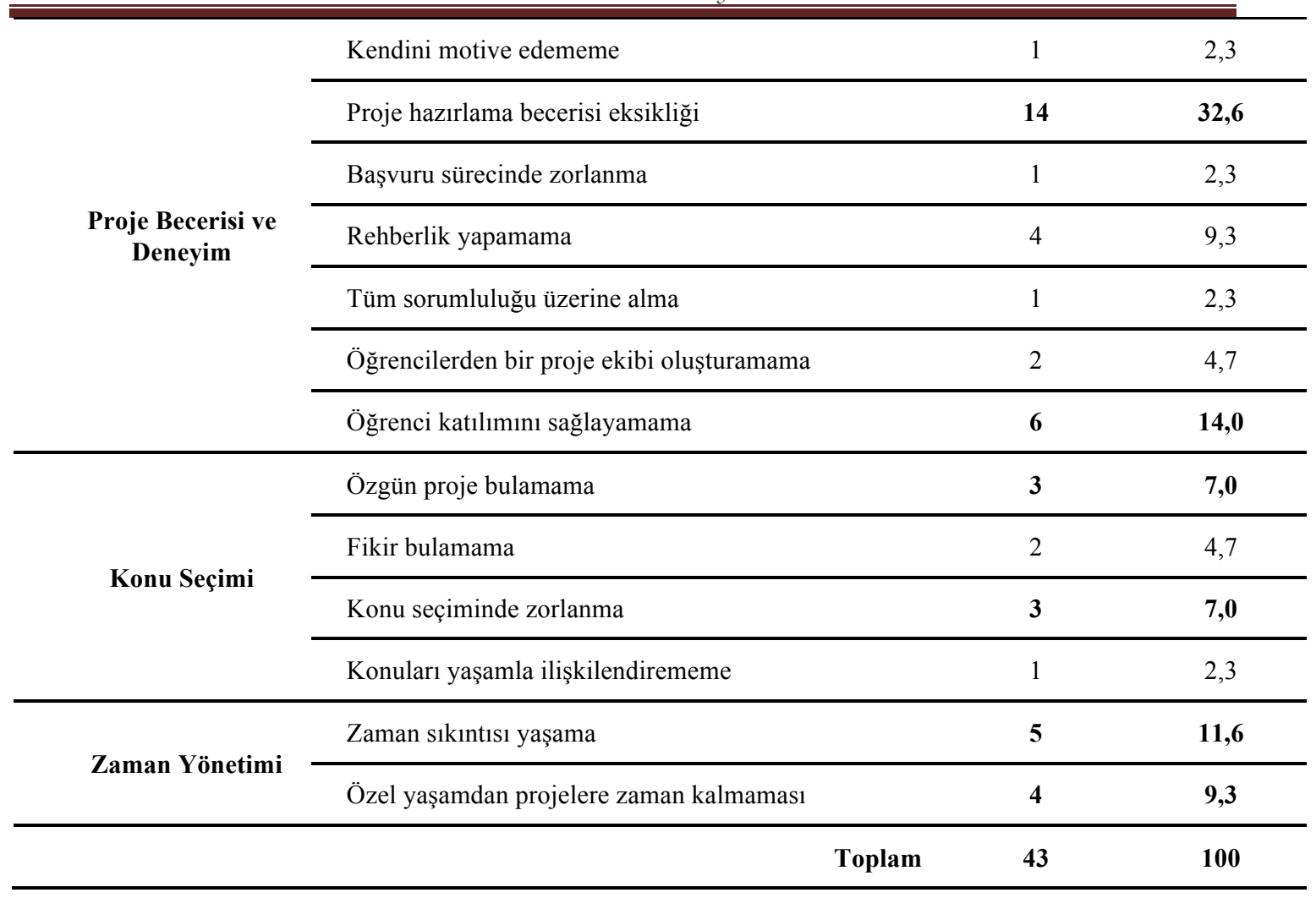

Tablo 4.'te yer alan bulgular incelendiğinde öğretmenlerin bireysel anlamda karşılaştıkları güçlüklerin temelde, "Proje hazırlama Becerisi ve Deneyim", "Konu Seçimi" ve "Zaman Yönetimi" olmak üzere üç temada toplandığ 1 görülmektedir. Öğretmenlerin "Proje becerisi ve deneyim" teması altında toplanan düşüncelerinin "Proje hazırlama becerisi eksikliği" ve "Öğrenci katılımını sağlayamama" kodlarında yoğunlaştığı görülmektedir. Bu kodlara ilişkin katılımcı ifadeleri aşağıda sunulmuştur.

K-42. Yarışmayı kazanan projelerde beklentiler tam olarak nedir, raporlarda net neler yazılmalıdır. Bu aşamaların ilerlemesi konusunda az bilgim olduğunu düşünüyorum - "Proje hazırlama becerisi eksikliği"

K-31. Ekip çalışması olduğu için ekip oluşturmakta ve destekleme aşamasinda zorlukla karşılaştım - "Öğrenci katılımını să̆layama"

İlgili tabloya bakıldı̆̆ında, "Konu Seçimi” teması altında "Özgün proje bulamama”, ve "Konu seçiminde zorlanma" kodlarının ön plana çıktığı gözlemlenmektedir. Ayrıca konu seçimi teması altına giren kodların çoğunlukla matematik öğretmenleri tarafından ifade edildiği dikkat çekmektedir. "Konu Seçimi” temasıyla ilgili katılımcı ifadelerinden birkaçı aşağıda sunulmuştur:

K-6. Daha önce hazırlanmamış proje bulmak zor oluyor. Çünkü matematik biliminin günlük hayatla ilişkilendirmesi daha minimum. -“Özgün proje bulamama”

K-12. Konu seçiminde problem yaşıyorum. Seçtiğim konu ya çok basit ya da çok kompleks oluyor. - "Konu seçiminde zorlanma" 
Ayrıca, katılımcıların "Zaman yönetimi” konusunda "Zaman sıkıntısı yaşama” ve "Özel yaşamdan projelere zaman ayıramama" durumlarından kaynaklı olarak sorun yaşadıkları görülmektedir. Katılımcı ifadeleri incelendiğinde:

K-21. Projeler için ekstra zaman harcamam gerekiyor, bu nedenle zamanımı verimli kullanamiyorum - "Zaman sikıntısı yaşama"

K-15. Proje için ciddi zaman ayırmak gerekiyor, ailem bu durumdan şikayetçi olabiliyor - "Özel yaşama zaman ayırma"

Öğretmenlerin BBE proje yarışmalarında maddi açıdan karşılaştıkları zorluklar ve katılımlarına engel durumlar değerlendirilmiş ve Tablo 5.'te sunulmuştur.

Tablo 5. Öğretmenlerin BBE proje yarışmalarında karşılaştığ “maddi” zorluklar ve katılımlarına engel durumlar

\begin{tabular}{|c|c|c|c|}
\hline Tema & Kod & f & $\%$ \\
\hline \multirow{7}{*}{ Maddi Güçlükler } & Yeterli ödenek sağlanmaması & 12 & 34,3 \\
\hline & Araç-gereç sağlanmaması & 5 & 14,3 \\
\hline & Kaynak bulma sorunu & 2 & 5,7 \\
\hline & Teknik desteğin yetersiz olması & 1 & 2,9 \\
\hline & Büyük bütçeli projelerin yapılamaması & 3 & 8,6 \\
\hline & Öğretmenin bütçeyi üstlenmesi & 2 & 5,7 \\
\hline & Verilen desteğin sınırlı kalması & 1 & 2,9 \\
\hline $\begin{array}{l}\text { Öğretmenin } \\
\text { Beklentileri }\end{array}$ & Patent hakkı olmaması & 2 & 5,7 \\
\hline \multirow{4}{*}{ Engelleri Aşabilme } & Maddi zorluk çözülebilir & 2 & 5,7 \\
\hline & Maddi zorluk yaşamama & 4 & 11,4 \\
\hline & Araç-gereç desteği sağlanıyor & 1 & 2,9 \\
\hline & Toplam & 35 & 100 \\
\hline
\end{tabular}

Tablo 5.'te yer alan bulgular incelendiğinde öğretmenlerin maddi açıdan karşılaştıkları güçlüklerin temelde, "Maddi Güçlükler", "Öğretmenin Beklentileri” ve "Engelleri Aşabilme" olmak üzere üç tema altında toplandığg görülmektedir. Öğretmenlerin "Maddi Güçlükler" teması altında toplanan düşüncelerinin "Yeterli ödenek sağlanmaması" ve "Araç-gereç sağlanmaması" kodlarında yoğunlaştığı görülmektedir. Bu kodlara ilişkin katılımcı ifadelerinden üç örnek aşağıda sunulmuştur.

K-1. Genellikle proje hazırlamada maddiyatı kendi cebimizden karşlllyoruz. Maddi olarak projelere ödenek sağlanmaması ciddi bir zorluk oluşturuyor. -

"Yeterli ödenek sağlanmamasi" 
K-15. Okulda hazırlanan projelerin maliyetinin az olmasl isteniyor. Bu konuda kısıtlandı̆̆ımı için ögrenciler maketini yapmakta bile yetersiz kalabiliyor. Bu konuda ailelerimiz de destek olamayabiliyor. Illk yll maketini yapamadı̆̆ımı proje ikinci yllında başka bir okul tarafindan gerçekleştirilmiş ve final sergisine katılmışt. Bu duruma öğrencim ve ben çok üzüldük. - "Yeterli ödenek sağlanmaması"

K-5. Çalıştığım ilçede malzeme ve materyal konusunda sılkıntı yaşanması sebebiyle daha önce proje hazırlayamadım. - "Araç-gereç sağlanmaması"

İlgili tabloya bakıldı̆̆ında, "Öğretmenin Beklentileri" teması altında "Patent hakkl olmaması" kodunun yer aldığ 1 gözlemlenmektedir. "Öğretmenin Beklentileri" temasıyla ilgili katılımcı ifadesi aşağıda sunulmuştur:

K-13. Projeleri herkes görebiliyor. Bu durumda proje patenti almadiğımız için herhangi birisi projeyi rahatllkla kullanabilir. - "Patent hakkı olmaması"

Ayrıca, projelerde karşılaşılan maddi güçlüklerle ilgili olarak katılımcıların "Engelleri Aşabilme" teması altında toplanan düşünceleri çoğunlukla "Maddi zorluk yaşamama" olarak ifade ettikleri görülmektedir. $\mathrm{Bu}$ koda ilişkin katılımcı ifadeleri aşağıda sunulmuştur:

K-48. Özel okulda öğretmenlik yaptığımdan maddi bir zorluk yaşamıyorum. "Maddi zorluk yaşamama"

Öğretmenlerin BBE proje yarışmalarında zaman açısından karşılaştıkları zorluklar ve katılımlarına engel durumlar değerlendirilmiş ve Tablo. 6' da sunulmuştur.

Tablo 6.'da yer alan bulgular incelendiğinde, öğretmenlerin BBE proje yarışmalarında karşılaştığı zaman açısından zorluklar ve katılımlarına engel durumların "Sistem Temelli", "Öğretmen Temeli" ve "Öğrenci Temelli" temaları altında toplandığı anlaşılmaktadır. "Sistem Temelli"," temasının altında, "Proje dışı" ve "Proje kaynaklı" alt temalarının oluştuğu görülmektedir. "Proje dışı" alt temasında öne çıkan katılımcı düşünceleri "TEOG sinavları" ve "Yoğun müfredat" ile ilgili durumları ifade etmektedir. Öğretmenlerin bu kodlara ilişkin ifadelerinden bazıları aşağıda sunulmuştur:

Tablo 6. Öğretmenlerin BBE proje yarışmalarında “zaman açısından” karşılaştığı zorluklar ve katılımlarına engel durumlar 


\begin{tabular}{|c|c|c|c|c|}
\hline \multirow{6}{*}{ Sistem temelli } & \multirow{3}{*}{ Proje dış1 } & $\begin{array}{l}\text { Temel Eğitimden Ortaöğretime Geçiş } \\
\text { (TEOG) sınavları }\end{array}$ & 13 & 19,7 \\
\hline & & Taşımalı eğitim & 4 & 6,1 \\
\hline & & Yoğun Müfredat & 9 & 13,6 \\
\hline & \multirow{3}{*}{ Proje kaynaklı } & $\begin{array}{l}\text { Müfredatta proje için ayrı zaman dilimi } \\
\text { olmaması }\end{array}$ & 6 & 9,1 \\
\hline & & BBE takviminin k1sitll11 $\breve{g}_{1}$ & 2 & 3,0 \\
\hline & & Sergilerin zaman alması & 1 & 1,5 \\
\hline \multirow{2}{*}{ Öğretmen temelli } & & Zamanı öğretmenin yaratması & 7 & 10,6 \\
\hline & & Öğretmenin iş yükü & 19 & 28,8 \\
\hline \multirow[t]{2}{*}{ Öğrenci temelli } & & Öğrenci ders yükü & 5 & 7,6 \\
\hline & & Toplam & 66 & 100 \\
\hline
\end{tabular}

K-8. Son sinıfların derslerine giren bir öğretmenim. Bu nedenle öğrencileri TEOG sınavina hazırlyyorum. Benim her teneffüsüm ve öğle aralarım soru çözmek, cevaplamak hatta soru hazırlamak ile geçiyor. Hatta okul saatleri sonrası da öğrencilerime kurs veriyorum, kendi okulumuzda. - "TEOG sinavlarl"

$K$-47. Öğrencilerin TEOG sinavı için test sorusu çözmek zorunda kalmalart proje çalışmalarının önünde ciddi bir engel diye düşünüyorum. - "TEOG sinavlart"

K-55. Yetişmesi gereken müfredat başka yönlere yönelmeyi engelliyor. - "Yoğun Müfredat"

"Proje kaynakll" alt temasında öne çıkan katılımcı düşünceleri ise "Müfredatta proje için ayrı zaman dilimi olmaması" ile ilgili durumları ifade etmektedir. Öğretmenlerin bu durumlara ilişkin ifadelerinden bazıları aşağıda sunulmuştur:

K-26. Okul sonrası yapılan egzersizler yeterli değil, seçmeli ders olmalı."Müfredatta proje için ayrı zaman dilimi olmaması"

"Öğretmen Temelli" temasında öne çıkan katılımcı düşünceleri ise "Zamanı ögretmenin yaratması" ve "Öğretmenin iş yükü" ile ilgili durumları ifade etmektedir. Öğretmenlerin bu durumlara ilişkin ifadelerinden bazıları aşağıda sunulmuştur:

\section{K-9. Proje hazırlamaya gönül verince zaman yaratıllyor. - "Zamanı öğretmenin yaratmast" \\ K-16. Okuldaki ders yükü, okulda bizlerden istenen ekstra işlerin zaman kaybına yol açması - "Öğretmenin iş yükü"}

"Öğrenci Temelli" temasında öne çıkan katılımcı düşünceleri ise “Öğrenci ders yükü” ile ilgili durumları ifade etmektedir. Öğretmenlerin bu durumlara ilişkin ifadelerinden bazıları aşağıda sunulmuştur: 
K-4. Öğrencilerin ders yüklerinden dolayı proje çalışmasındaki sorumluluklarını tam olarak yerine getirememesi. - "Ögrrenci ders yükü"

Öğretmenlerin BBE proje yarışmalarında sınıf ortamı açısından karşılaştıkları zorluklar ve katılımlarına engel durumlar değerlendirilmiş ve Tablo 7.'de sunulmuştur.

Tablo 7. Öğretmenlerin BBE proje yarışmalarında karşılaştığı "sınıf ortamı açısından” zorluklar ve katılımlarına engel durumlar

\begin{tabular}{clll}
\hline Tema & \multicolumn{1}{c}{ Kod } & f & \% \\
\hline \multirow{4}{*}{ Sınıf dinamiği } & Kalabalık sınıfların olması & 1 & 5,9 \\
\cline { 2 - 4 } & Projeye uygun olmayan ortam & 1 & 5,9 \\
\cline { 2 - 4 } & Sinıf içi rekabet & 1 & 5,9 \\
\cline { 2 - 4 } & Sinıfı teşvik edememe & 1 & 5,9 \\
\cline { 2 - 4 } & Grup çalışması sorunu & $\mathbf{2}$ & $\mathbf{1 1 , 8}$ \\
\hline $\begin{array}{c}\text { Mekânsal } \\
\text { Sorunlar }\end{array}$ & Laboratuvar eksikliği & $\mathbf{6}$ & $\mathbf{3 5 , 3}$ \\
\cline { 2 - 4 } & Fiziki imkan yetersizliği & $\mathbf{5}$ & $\mathbf{2 9 , 4}$ \\
\hline
\end{tabular}

Tablo 7.'de yer alan bulgular incelendiğinde, öğretmenlerin BBE proje yarışmalarında karşılaştığı sınıf açısından zorluklar ve katılımlarına engel durumların "Sinıf Dinamiği", ve "Mekansal Sorunlar" temaları altında toplandığı anlaşılmaktadır. "Sınıf Dinamiği", temasının altında öne çıkan katılımcı düşüncelerine ilişkin ifadelerinden bazıları aşağıda sunulmuştur:

K-12. Öğrencileri grup çalışması açısından görevlendirmede, iş bölümü yapma konusunda sorun yaşıyorum.- "Grup çalışması sorunu"

"Mekansal Sorunlar", temasının altında öne çıkan katılımcı düşüncelerinden "Laboratuvar eksikliği" ve "Fiziki imkan yetersizliği" kodlarına ilişkin ifadelerinden bazıları aşağıda sunulmuştur:

K-1. Okulda işlevsel bir laboratuvar ortamının olmamasl, proje hazırlamada çalışmaların sadece sinıf ortamına bağlı olmast. - "Laboratuvar eksikliği"

K-40. Okullarda bu projeleri uygulayacak alan ve donanımlarımı yok. - "Fiziki imkan yetersizliği"

Öğretmenlerin BBE proje yarışmalarında öğrenci açısından karşılaştıkları zorluklar ve katılımlarına engel durumlar değerlendirilmiş ve Tablo 8.'de sunulmuştur. 
Tablo 8. Öğretmenlerin BBE proje yarışmalarında “öğrenci açısından” karşılaştığı zorluklar ve katılımlarına engel durumlar

\begin{tabular}{|c|c|c|c|}
\hline Tema & Kod & f & $\%$ \\
\hline \multirow{5}{*}{ İsteklilik } & Öğrenci isteksizliği & 13 & 21,0 \\
\hline & Proje sürecinde ilginin azalması & 1 & 1,6 \\
\hline & Merak eksikliği & 2 & 3,2 \\
\hline & Bilgilendirme ve teşvik eksikliği & 3 & 4,8 \\
\hline & İstekliler & 2 & 3,2 \\
\hline \multirow{4}{*}{ Beceri } & Projeyi zor bir etkinlik olarak görme & 2 & 3,2 \\
\hline & Öğrencinin yeterlilik düzeyi & 5 & 8,1 \\
\hline & Türkçeyi kullanamama & 1 & 1,6 \\
\hline & Proje deneyimi eksikliği & 1 & 1,6 \\
\hline \multirow{3}{*}{ Proje Konusu } & Hayal gücünü kullanamama & 7 & 11,3 \\
\hline & Özgün proje konusu bulamama & 6 & 9,7 \\
\hline & Konuyu öğretmenden bekleme & 1 & 1,6 \\
\hline \multirow{4}{*}{ Zaman } & Proje için zaman bulamama & 1 & 1,6 \\
\hline & Proje yapmayı zaman kaybı olarak görme & 4 & 6,4 \\
\hline & Derslerin yoğunluğu & 2 & 3,2 \\
\hline & Sinav kaygis1 & 2 & 3,2 \\
\hline \multirow{4}{*}{ Maddiyat ve Beklenti } & Maddi sıkıntı & 2 & 3,2 \\
\hline & Not beklentisi & 6 & 9,7 \\
\hline & Maddi destek beklentisi & 1 & 1,6 \\
\hline & & 62 & 100 \\
\hline
\end{tabular}

Tablo 8.'de yer alan bulgular incelendiğinde, öğretmenlerin BBE proje yarışmalarında karşılaştığı öğrenci açısından zorluklar ve katılımlarına engel durumların "İsteklilik", "Beceri", "Proje konusu", "Zaman" ve "Maddiyat ve Beklenti" temaları altında toplandığı anlaşılmaktadır. "Ísteklilik" temasının altında öne çıkan katılımcı düşüncelerine ilişkin ifadelerinden bazıları aşağıda sunulmuştur:

K-1. Proje için istekli öğrencilerin zaman içerisinde sinav, aile ve maddi unsurlardan kaynaklı olarak vazgeçtiklerini gördüm. - "Öğrenci isteksizliği”"

K-25. Öğrencilerin hedefi iyi bir liseye yerleşebilmek. Bu konular ile uğraşmak istemiyorlar. Bilgisayar-TV gibi araçların olumsuz etkileri ile birleşince projeler ile ilgilenmek istemiyorlar. - "Öğrenci isteksizliği"

"Beceri” temasının altında öne çıkan katılımcı düşüncelerine ilişkin ifadelerinden bazıları aşağıda sunulmuştur:

K-21. Öğrencilerimizin kapasiteleri çok düşük. Düşünen, üreten ögrenci sayımız çok az. Onlarda sinav hazırlıklarıyla uğraşıyorlar.- "Öğrencinin yeterlilik düzeyi" $K$-23. Ö̆grencilerimizin bilimsel süreç becerilerinde henüz yeterli olmayışı BBE gibi yarışmaların yönetimini büyük ölçüde etkiliyor. Öğrencilerimizin deneysel becerilerini gelişstirebileceğimiz ölçüde yarlşmalara daha sıcak bakacaklarını düşünüyorum.- "Öğrencinin yeterlilik düzeyi"

"Proje Konusu” temasının altında öne çıkan katılımcı düşüncelerine ilişkin ifadelerinden bazıları aşağıda sunulmuştur: 
K.46. Öğrencilerimin genelinde hayal gücünün zaylf olduğunu gözlemliyorum. "Hayal gücünü kullanama"

K.55. Öğrencilerimin hayal güçlerinin kısıtlanmış olması ve ezbere dayalı ögrenmeleri sorun oluyor. - "Hayal gücünü kullanama"

K.7. Benim ögrencilerim orijinallik konusunda sıkıntı yaşıyorlar. Ya var olan projelerle ilgili fikirler (yani taklit) geliyor ya da yeni bir şey bulamayı diye düşünüyorlar.- "Özgün proje bulamama"

"Zaman" temasının altında öne çıkan katılımcı düşüncelerine ilişkin ifadelerinden bazıları aşağıda sunulmuştur:

K.29. Öğrencilerim yarışmaya katılmak istemiyor. Yarışmaya zaman ayırmak yerine ders çalışmayı veya başka uğraşlar edinmeyi tercih ediyorlar. -"Zaman kaybı olarak görme"

“Maddiyat ve Beklenti” temasının altında öne çıkan katılımcı düşüncelerine ilişkin ifadelerinden bazıları aşağıda sunulmuştur:

K-51. Proje denilince mutlaka çıkar beklentisi içine giriyorlar. Projelerinin not olarak değerlendirilmesini istiyorlar. İsteklerini kıramıyorum fakat çocuklar proje hazırlamaya genel itibariyle mesafeli duruyorlar. - "Not beklentisi"

K-9. Maddi destek să̆lama açısından zorluk çekiyorlar. - "Maddi sıkıntı"

Öğretmenlerin BBE proje yarışmalarında veli açısından karşılaştıkları zorluklar ve katılımlarına engel durumlar değerlendirilmiş ve Tablo 9.'da sunulmuştur.

Tablo 9. Öğretmenlerin BBE proje yarışmalarında veli açısından karşılaştıkları zorluklar

\begin{tabular}{|c|c|c|c|}
\hline Tema & Kod & f & $\%$ \\
\hline \multirow{5}{*}{ Akademik kaygı } & Öğrenci başarısının düşme endişesi & 9 & 19,1 \\
\hline & Zaman kaybı olarak görme & 6 & 12,8 \\
\hline & Sınav odaklı başarı & 7 & 14,9 \\
\hline & Not beklentisi & 1 & 2,1 \\
\hline & Bilgisizlik & 1 & 2,1 \\
\hline \multirow{5}{*}{ Destek } & İlgisizlik & 7 & $\mathbf{1 4 , 9}$ \\
\hline & Gereksiz görme & 2 & 4,3 \\
\hline & Öğrenciyi teşvik etmeme & 1 & 2,1 \\
\hline & Teşvik edici & 1 & 2,1 \\
\hline & Destek verici & 2 & 4,3 \\
\hline \multirow{3}{*}{ Korumacılık } & Bölge sergisi için öğrencilerin evden uzaklaşması & 4 & 8,5 \\
\hline & Öğrencileri köyde çalıştırma & 1 & 2,1 \\
\hline & Veli tepkisi & 1 & 2,1 \\
\hline \multirow[t]{2}{*}{ Maddiyat } & Maddi yük & 4 & 8,5 \\
\hline & Toplam & 47 & 100 \\
\hline
\end{tabular}

Tablo 9.'da yer alan bulgular incelendiğinde, öğretmenlerin BBE proje yarışmalarında karşılaş̧ı̆̆ı veli açısından zorluklar ve katılımlarına engel durumların "Akademik kaygl", "Destek", "Korumacılık" ve "Maddiyat" temaları altında toplandığı anlaşılmaktadır. "Akademik kaygl" temasının altında öne çıkan katılımcı düşüncelerine ilişkin ifadelerinden bazıları aşağıda sunulmuştur: 
K-7. Öğretmenlik yaptı̆̆ım okuldaki velilerim öğrencilerin sınıfta başarılı (sınavlarda başarılı) olmalarını istiyorlar, notlarının düsseceğinden korkuyorlar. "Öğrenci başarısının düşme endişesi"

$K$-6. Öğrencilerin eğitim sistemi nedeniyle velileri tarafindan daha çok ders içerikli etkinliklere yönlendirilmesi. Spor etkinlikleri ve bu tarz yarışmaları zaman kaybı olarak görmeleri. - "Zaman kaybı olarak görme"

K-51. Özellikle 8. sinıflarda veliler TEOG kaygısı içerisinde oldukları için ögrencilerin yalnızca sınava odaklanmasını istiyorlar. - "Sinav odakl başarı"

K-52. Öğrencilerin bu tip etkinlikler ile uğraşmalart yerine sinava çalışmalarından yanalar. - "Sinav odaklı başarı"

"Destek" temasının altında öne çıkan katılımcı düşüncelerine ilişkin ifadelerinden bazıları aşağıda sunulmuştur:

K-8. Velilerin ilgisiz olması, ögrencileri okula yalnızca başlarından savmak için göndermeleri büyük bir sikıntı. Gerçekten bulunduğum köy, aile konuları bakımından çok sikıntılar çeken ögrenciler ile dolu. - "İlgisizlik"

"Korumacılık” temasının altında öne çıkan katılımcı düşüncelerine ilişkin ifadelerinden bazıları aşağıda sunulmuştur:

K-6. Özellikle bölge sergisine katılımda klz öğrenci velileri izin vermek istemiyor.

- "Bölge sergisi için ögrencilerin evden uzaklaşmast"

"Maddiyat" temasının altında öne çıkan katılımcı düşüncelerine ilişkin ifadelerinden bazıları aşağıda sunulmuştur:

K-1. Öğrenci velileri maddi açıdan projelerin kendilerine yük olacaklarını düşünüyor. - "Maddi yük"

Öğretmenlerin BBE proje yarışmalarında okul yönetimi açısından karşılaştıkları zorluklar ve katılımlarına engel durumlar değerlendirilmiş ve Tablo 10.'da sunulmuştur. 


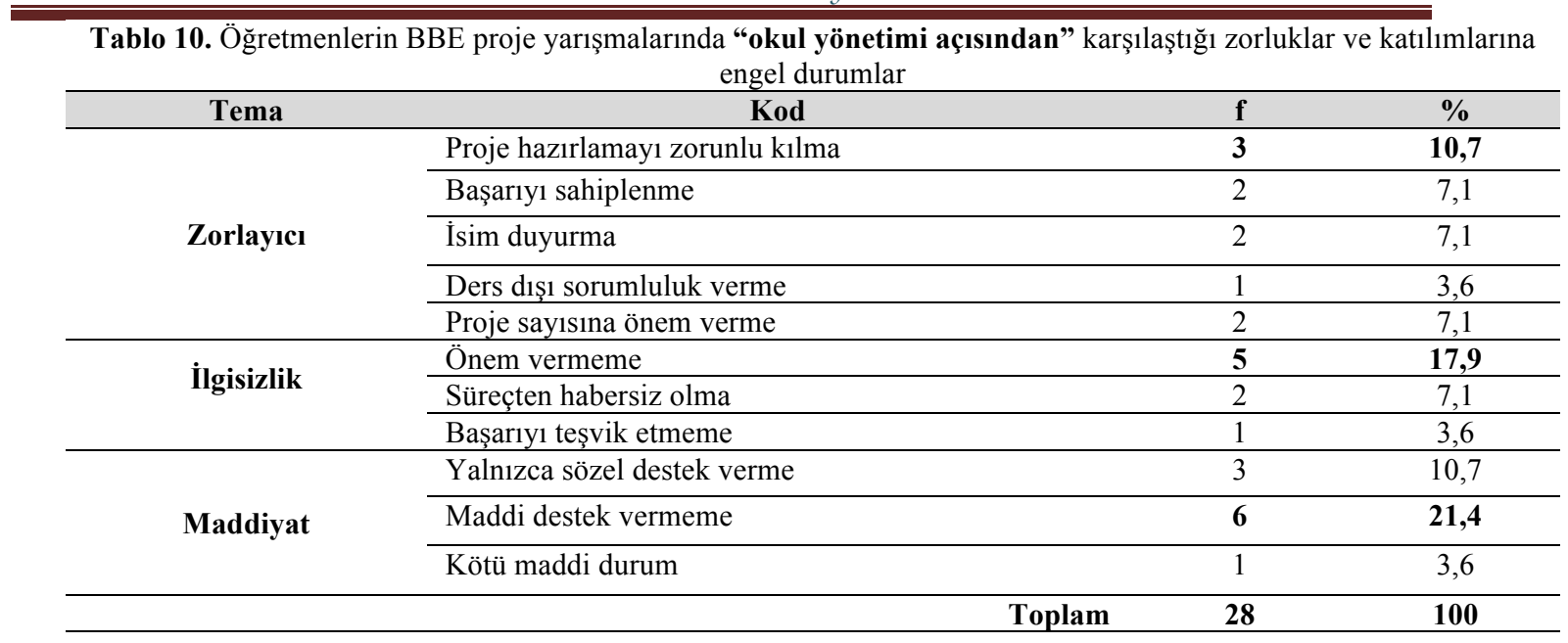

Tablo 10.'da yer alan bulgular incelendiğinde, öğretmenlerin BBE proje yarışmalarında karşılaştığı okul yönetimi açısından zorluklar ve katılımlarına engel durumların "Zorlayıcı", "Ilgisizlik" ve "Maddiyat" temaları altında toplandığı anlaşılmaktadır. "Zorlayıcı" temasının altında öne çıkan katılımcı düşüncelerine ilişkin örnek ifade aşağıda sunulmuştur:

K-13. Okul yönetimi proje hazırlamayı zorunlu birakıyor, bazı dönemlerde böyle olunca gönüllülük olmadı̆̆ı için ögrrenci de ben de katılmış olmak için basit projelerle katıllyoruz. - "Proje hazırlamayı zorunlu kılma"

"İlgisizlik" temasının altında öne çıkan katılımcı düşüncelerine ilişkin ifadelerinden bazıları aşağıda sunulmuştur:

K-52. Okul yöneticileri bu projeler sonunda okula ve ögrenciye hiçbir getirisi olmadiğını düşünüyor, bu yüzden bu tür etkinliklere katılmaya sıcak bakmıyor. "Önem vermeme"

"Maddiyat" temasının altında öne çıkan katılımcı düşüncelerine ilişkin ifadelerinden bazıları aşağıda sunulmuştur

K-12. Okul yönetimi projenin bütçe vs. konusunda her şeyi ögretmenden bekliyor. Bütçe yok diyor. - "Maddi destek vermeme"

Öğretmenlerin BBE proje yarışmalarında İl ve İlçe Milli Eğitim Müdürlükleri açısından karşılaş̧ıkları zorluklar ve katılımlarına engel durumlar değerlendirilmiş ve Tablo 11.'de sunulmuştur. 
Tablo 11. Öğretmenlerin BBE proje yarışmalarında “ỉ ve İlçe Milli Eğitim Müdürlükleri” ile ilgili olarak karşılaştıkları zorluklar ve katılımlarına engel durumlar

\begin{tabular}{|c|c|c|c|}
\hline Tema & Kod & $\mathbf{f}$ & $\%$ \\
\hline \multirow{3}{*}{ Yaklaşım } & Reklam amacı gütme & 1 & 3,4 \\
\hline & Proje hazırlamaya yönelik bask1 & 2 & 6,9 \\
\hline & Yalnızca proje sayısına önem verme & 4 & 13,8 \\
\hline \multirow{4}{*}{ İlgi } & Destek eksikliği & 2 & 6,9 \\
\hline & MEB-Öğretmen iletişimsizliğ $i$ & 2 & 6,9 \\
\hline & Teşvik edici değil & 5 & 17,2 \\
\hline & Destekliyor & 9 & 31,0 \\
\hline \multirow{4}{*}{ Ĕ̆itim } & Seminerlerde uygulamalara yer verilmemesi & 2 & 6,9 \\
\hline & Hizmet içi eğitimlerin yetersiz olması & 1 & 3,4 \\
\hline & Uzman eğitmen sayısının az olması & 1 & 3,4 \\
\hline & Toplam & 29 & 100 \\
\hline
\end{tabular}

Tablo 11.'de yer alan bulgular incelendiğinde öğretmenlerin proje hazırlama sürecinde İl ve İlçe Milli Eğitim Müdürlüklerine karşı bakış açılarının "Yaklaşım”, "İlgi” ve "Eğitim" temaları altında toplandığı anlaşılmaktadır. "Yaklaşım" temasının altında öne çıkan katılımcı düşüncelerine ilişkin ifadelerinden bazıları aşağıda sunulmuş̧tur:

K-6. Proje hazırlamada sadece niceliğe önem veriliyor. En son değişiklikle her ögretmenin en fazla üç projeye rehberlik edebilmesi bu sorunun önüne geçse de iyi projenin sayıdan önemli olduğunu unutmamak gerekiyor.- "Yalnızca proje sayısina önem verme"

"İlgi" temasının altında öne çıkan katılımcı düşüncelerine ilişkin ifadelerinden bazıları aşağıda sunulmuştur:

K-2. Öğretmenler için teşvik amaçlı bir "teşekkür” yazısı bile yazılmıyor. - "Teşvik edici değil"

K-1. Il her zaman destekleyici oldu. Illde ARGE birimi hep yanımızda. - "Destekliyor"

"Eğitim” temasının altında öne çıkan katılımcı düşüncelerine ilişkin ifadelerinden bazıları aşağıda sunulmuştur:

K-7. Öğretmenlere gerçekten işe yarayacak seminerler vermiyorlar. Bizleri toplayıp bir slayt ya da konuşmacı karşısında saatlerce oturtup bildiğimiz ya da kullanmayacağımız konuların seminerleri veriliyor. Uygulamalı seminerler çok çok yetersiz. - "Yetersiz hizmet içi ĕgitim"

Öğretmenlerin BBE proje yarışmalarında karşılaştıkları zorluklar ve katılımlarına engel diğer durumlar değerlendirilmiş ve Tablo 12.'de sunulmuştur. 
Tablo 12. Öğretmenlerin BBE proje yarışmalarında karşılaştı̆̆ "Diğer" zorluklar ve katılımlarına engel durumlar

\begin{tabular}{cllcc}
\hline Tema & \multicolumn{1}{c}{ Kod } & f & \% \\
\hline \multirow{4}{*}{ Diğer } & Öğretmen ya da velinin projeyi kendilerinin hazırlaması & $\mathbf{5}$ & $\mathbf{5 0}$ \\
\cline { 2 - 5 } & Özel okulların avantajlılması & $\mathbf{3}$ & $\mathbf{3 0}$ \\
\cline { 2 - 5 } & Öğretmenler arası rekabet & 1 & 10 \\
\cline { 2 - 5 } & İl çalışma grubu kriterlerinin güvenilir olmaması & 1 & 10 \\
\hline & & Toplam & $\mathbf{1 0}$ & $\mathbf{1 0 0}$ \\
\hline
\end{tabular}

Tablo 12.'de yer alan bulgular incelendiğinde, öğretmenlerin BBE proje yarışmalarında karşılaştı̆̆ "Diğer" zorluklar ve katılımlarına engel durumlara ilişkin ifadelerinden bazıları aşağıda sunulmuştur:

K-6. Bu tarz yarışmaların öğrenci merkezli olduğunun unutulup, öğretmenler arası bir yarış hatta "savaş" şekline dönüşmesi (bazı projelerin ögrenciler tarafindan hazırlandiğına inanabilmek gerçekten zor oluyor). Öğretmenin proje hazırlayan değil rehberlik eden olduğunun unutulmaması gerekiyor. - "Öğretmen ya da velinin projeyi kendilerinin hazırlaması"

K-1. Devlet okullarının özel okul ve bilim merkezleriyle yarışmada olması, bizlerin imkanları ile onların eş olmaması. - "Özel okulların avantajlı olması"

\section{Tartışma ve Sonuç}

Mevcut araştırmada BBE Proje Yarışmasına hazırlık sürecinde öğretmenlerin bireysel, maddi, zaman, sınıf ortamı, öğrenci, öğrenci velisi, okul yönetimi, il/ilçe milli eğitim müdürlüğü ve diğer etmenlerden kaynaklı olarak karşılaştığı zorluklar ve katılımlarına engel durumlar incelenmiştir. $\mathrm{Bu}$ amaçla geliştirilen veri toplamaaracı ile ilk olarak öğretmenlerin proje hazırlamada kendilerinde gözlemledikleri eksiklikler ve eğitim alma ihtiyacı duydukları durumlar incelenmiştir. Öğretmenlerin benzer çalışmalarda Schneider ve Lumpe (1996)'da olduğu gibi genel olarak bir projenin nasıl hazırlanacağı ile ilgili bilgi edinmek istedikleri görülmektedir. Ancak buradaki genel eğilim katılımcı ifadelerinden de anlaşlacağ 1 üzere proje hazırlama aşamasında bilimsel temelli rehberlikten çok teknik açıdan bir projenin hazırlanması ve tamamlanması sürecidir. Öğretmenlerin teknik öğrenme odaklı bu düşünceleri uzun vadede bilimsel temelli projelerin oluşmasına engel olabilmektedir.

Bunun yanında katılımcıların, öğrencileri proje sürecinde nasıl yönlendirecekleri, rehberlik yapacakları ve motive edecekleri konusunda yardıma ihtiyaç duydukları anlaşılmaktadır. Proje yarışmalarının öğrenciye sağladığı katkılar, projelerin yarışma sürecine ulaşabildiği ölçüde beklendik kazanımlar ile sonuçlanabilmektedir. Projelerin yarışma sürecine ulaşması da öğretmenin rehberliği ve öğrencinin motivasyonu ile doğrudan ilişkilidir. Öğretmen bu süreçte öğrenciye sıradan gözlemleri araştırılabilecek sorulara nasıl dönüştürebileceği, projeye odaklayıcı doğru soruları seçme, soruya cevap verebilecek doğru veri toplama yöntemlerini belirleme, verileri analiz ve görselleştirmede belirli bir çerçeve oluşturma gibi anahtar noktalarda çerçeve oluşturarak rehberlik yapmalıdır (Windschitl, 2003). Son olarak bireysel anlamda öğretmenlerin, diğer öğretmen ve akademisyenlerle paylaşım içinde bulunarak proje sürecini daha kolay bir şekilde geçirebilme ve özgün fikirler üretebilme konusunda da beklentileri ön plana çıkmaktadır. Öğretmenlerin BBE proje yarışmalarında karşılaştığı bireysel zorluklar ve katılımlarına engel durumlar genel olarak değerlendirildiğinde ise, öğretmenlerin özellikle proje hazırlama konusunda kendilerini yetersiz hissettikleri, çoğunlukla da bir araştırmaya 
başlangıç olarak problemlere odaklanmak ve bunları Nasıl çözebiliriz? diye düşünmek yerine, doğrudan proje konusu olarak Ne yapalım? sorusuna odaklandıkları dikkat çekmektedir. Özellikle matematik öğretmenlerinin özgün konu bulmakta zorlandıkları ve araştırma konularını günlük yaşam ile ilişkilendiremedikleri görülmektedir. Özgün bilimsel projeler ancak bilimsel düşünme süreçlerini kullanarak geliştirilebilir. Öğretmenlerin teknik bilgi odaklı öğrenme yaklaşımları proje üretimini sekteye uğratmaktadır.

Bunun yanında öğrencileri proje hazırlamaya teşvik etme, yönlendirme konularında da öğretmenler sıkıntı çekmektedir. Öğretmenlerin yaşadı ̆̆ı bir diğer sorun ise ailevi ve diğer sebeplerden dolayı proje hazırlamaya vakit bulamamalarıdır. Öğretmenlerin proje hazırlama sürecinde karşılaştıkları maddi zorluklar incelendiğinde ise yeterli maddi desteği bulamamaktan sıkıntı yaşadıkları anlaşılmaktadır. Öğretmenler bu desteği, okul yönetimlerinden ve Milli Eğitim Müdürlüklerinden sağlamayı beklemektedirler. Ancak öğretmenlerin ifadelerinden de anlaşılacağ sağlamada özel okulların sorunları olmadığı gözlenmiş̧tir.

Öğretmenlerin BBE proje yarışmalarında zaman açısından karşılaştıkları zorluklar ve katılımlarına engel durumlar değerlendirildiğinde ise öğretmenlerin ve öğrencilerin proje hazırlama sürecine diğer çalışmalarda da gözlendiği üzere zaman ayırmakta sorunlar yaşadıkları anlaşılmaktadır (Tortop, 2013, 2014). Bu durumun en önemli sebebini öğretmenler TEOG sınavı olarak görmektedir. TEOG sınavının oluşturduğu baskı hem öğretmenleri hem de öğrencileri proje hazırlama konusunda zorlayıcıdır. Buna karşın proje hazırlamaya istekli olan öğretmenlerin farklı şekillerde proje yarışması için zaman yaratabildikleri de görülmektedir.

Proje hazırlama sürecine sınıf ortamı açısından bakıldığında ise öğretmenlerin okullarındaki mekansal sorunlardan kaynaklı proje hazırlamada zorlandıkları ortaya çıkmaktadır. Özellikle okullardaki fen laboratuvarlarının yeterli düzeyde olmaması, öğretmelerin fen alanında gerçekleştirecekleri deneysel çalışmaları sınırlandırmaktadır.

Öğretmenlerin BBE proje yarışmalarında karşılaştığı öğrenci açısından zorluklar ve katılımlarına engel durumlar incelendiğinde ise öğrencilerin proje hazırlamaya yönelik isteksizlikleri ön plana çıkmaktadır. Bu isteksizlik öğrencinin proje kavramını tam olarak kavrayamamasından kaynaklanmaktadır. Çünkü öğrenciler, katılımcı ifadelerinden de anlaşılacağ 1 üzere projeleri ders ödevi gibi görmekte, not beklentisi içine girmekte ve hayal güçlerini kullanmadan daha önce yapılmış projelere yönlenmektedirler. Ayrıca öğretmenlerin, öğrencilerinin bilimsel süreç becerilerinin tam olarak gelişmediğini düşünmesi ve bu nedenle proje hazırlamaya yetkin olmadığı düşüncesi de araştırma sonuçlarında ön plana çıkmaktadır.

Bilim yarışmalarının öğrencilerin eğitim süreçlerinden beslenmesi, öğretmen ve öğrencinin dışında diğer bir paydaş olan velinin tutum ve yaklaşımından önemli ölçüde etkilenebilmektedir. Öğretmenlerin ifadeleri incelendiğinde velilerin, en çok öğrencinin başarısının düşmesi, çoğu zamanın proje için harcanması, sınavlara öğrencinin hazırlanamaması gibi akademik kaygılarla BBE proje yarışmasına mesafeli yaklaştıkları görülmüştür. Diğer bir taraftan velilerin projelere ilgi göstermemesi, kırsal kesimde yaşayan ailelerin öğrencileri bölge sergilerine göndermeyi istememeleri, ya da maddi açıdan projelerin getireceği yükü düşünerek öğrencilerin $\mathrm{BBE}$ proje yarışmalarına katılımlarını olumsuz etkiledikleri sonucuna ulaşılmıştır.

Okul yönetimleri proje hazırlama ve yarışma sürecinde öğretmene ve öğrenciye verecekleri destek, projelerin elektronik ortamda başvuru onaylarını kolaylaştırma gibi pek çok aşamayı etkileyebilmektedirler. Öğretmen ifadelerinde görüleceği üzere okul yönetimlerinin proje hazırlamayı zorunlu tutma gibi baskıcı yaklaşımları öğretmenlerin proje hazırlama süreçlerini olumsuz etkileyebilmektedir. Diğer taraftan bazı okul yöneticilerinin projelere önem vermemeleri, maddi anlamda öğretmeni ve öğrencileri 
desteklememe/destekleyememeleri proje hazırlama sürecini zorlaştırdığ 1 sonucuna ulaşıılmıştır.

Proje hazırlama sürecine ilişkin karşılaşılan çarpıcı bir durum ise öğretmenlerin ifadelerinde öğrencinin hazırlaması gereken projenin çeşitli nedenlerle öğretmen ya da veli tarafından hazırlanarak öğrenciye ait olarak gösterilmesidir. Diğer bir husus ise devlet okullarında çalışan öğretmenlerin özel okullarla rekabet içine girememeleridir. Teknik, maddi, danışmanlık ya da yönetimsel pek çok açıdan özel okul öğretmenlerinin proje hazırlamaya teşvik edildiği, ancak bu durumun devlet okul koşulları düşünüldüğünde pek mümkün olmadığı belirtilmiştir.

Sonuç olarak, öğretmenlerin proje beceri ve deneyimlerinin yetersizliği proje hazırlama süreçlerinin önünde önemli bir engel oluşturmaktadır. Proje hazırlama süreci bir kültürdür ve bu kültürün öğretmenlerde oluşturulması, dahası topluma yaygınlaştırılması gerekmektedir. Öğretmen ve öğrencinin hazırlayabilecekleri projeler; problem çözme becerisini geliştirmeye yönelik (problem çözme odaklı), bilim insanının yeterliliklerini kazandırmaya yönelik (süreç becerileri odaklı), tasarım ürünü oluşturmaya yönelik (tasarım ve mühendislik odaklı), ya da fen kavramlarını öğretmeye yönelik (konu/kavram odaklı) geniş bir çeşitliliktedir. Bu çeşitlilik içerisinde öğretmenlerin bir yerden başlaması, içsel ya da dışsal uyarıcılar ile başarı duygusunun güdülenmesi oldukça önemlidir. Dolayısıyla yöneticiler, öğrenciler ya da velilerin öğretmeni rehberliğe teşvik etme, bu süreçte üzerindeki baskıyı ve iş yoğunluğunu azaltma yönünde adımlar atması yukarıda sözü edilen proje kültürünün oluşturulmasında etkin olabilecektir. Özellikle öğretmenlerin örnek projeleri değerlendirebildikleri, kendi araştırma sorularını geliştirebildikleri ve rehberlik tecrübeleri üzerine tartışabildikleri uygulamalı eğitimler bu amaca destek verebilmektedir.

\section{Teşekkür}

Bizlere zorluklara karşı dik durmayı öğreten Merhume Arş. Gör. Hilal KÜÇÜK'e sonsuz teşekkürlerimizi sunuyoruz.

\section{Kaynakça}

Balas, A.K. (1998, updated 2003). Science fairs in elementary school. (ERIC Document Reproduction Service No. ED 432444)

Bruce, S.P., ve Bruce, B.C. (2000). Constructing images of science: People, technologies, and practices. Computers in Human Behavior, 16, 241-256.

Bunderson, E. D., ve Anderson, T. (1996). Preservice Elementary Teachers' Attitudes Toward Their Past Experience With Science Fairs. School Science and Mathematics, 96(7), 371-377. http://doi.org/10.1111/j.1949-8594.1996.tb15855.x

Cramer, H. (1999). Mathemaical methods of statistics. Princeton University press.

Dionne, L., Reis, G., Trudel, L., Guillet, G., Kleine, L., ve Hancianu, C. (2012). Students' Sources of Motivation for Participating in Science Fairs: An Exploratory Study within the Canada-Wide Science Fair 2008. International Journal of Science and Mathematics Education, 10(3), 669-693. Retrieved from http://eric.ed.gov/?id=EJ968021

Fisanick, L. M. (2010). A Descriptive Study Of The Middle School Science Teacher Behavior For Required Student Participation In Science Fair Competitions (Yayınlanmamış doktora tezi). Indiana University of Pennsylvania, ABD.

Grote, M. (1995a). Science teacher educators ${ }^{\text {ee }}$ opinions about science projects and science fairs. Journal of Science Teacher Education, 6(1), 48-52. 
Grote, M. (1995b). Teacher opinions concerning science projects and science fairs. Ohio Journal of Science, 95(4), 274-277.

National Institute of Aerospace (NIA). (2010). NASA Engineering Design Challenge About. Retrieved from http://www.nasarealworldinworld.org/About.aspx

Richards, T. (2002). An intellectual history of NUD*IST and NVivo. International Journal of Social Research Methodology, 5(3), 199-214.

Schneider, R.M., ve Lumpe, A.T. (1996). The nature of student science projects in comparison to educational goals for science. Ohio Journal of Science, 96(4/5), 81-88.

Society for Science ve the Public (SSP). (2015). About Intel ISEF. Retrieved from https://student.societyforscience.org/intel-isef

Temel Eğitim Genel Müdürlüğü - TGEM. (2014). Ortaokul Öğrencilerine Yönelik X. Matematik ve Fen Bilimleri "Bu Benim Eserim” Proje Yarışması Başvuru Kılavuzu. Ankara: $\quad$ MEB $\quad$ Temel Eğitim Genel Müdürlüğü. http://tegm.meb.gov.tr/bubenimeserim/kilavuz.pdfhttp://tegm.meb.gov.tr/bubenimeserim/k ilavuz.pdf

Tortop, H.S. (2013). Science Teachers' Views about the Science Fair at Primary Education Level, Turkish Online Journal of Qualitative Inquiry, 4(2), 56-64.

Tortop, H.S. (2014). Examining of the Predictors of Pre-service Teachers' Perceptions of the Quality of the Science Fair Projects in Turkey, Necatibey Eğitim Fakültesi Elektronik Fen ve Matematik Eğitimi Dergisi, 8(1), 8, 31-44.

United Nations Educational, Scientific and Cultural Organization (UNESCO). (1956). Science Teaching Service No:11, The Science Fair - Tool of Science Education. Study Conferance on Science Teaching, Bangkok, Thaland. 24 Haziran 2015 tarihinde http://unesdoc.unesco.org/images/0015/001546/154690eb.pdf adresinden alınmıştır.

Windschitl, M. (2003). Inquiry Projects in Science Teacher Education: What Can Investigative Experiences Reveal about Teacher Thinking and Eventual Classroom Practice? Science Education, 87(1), 112-143. http://doi.org/10.1002/sce.10044

Yıldırım, A. ve Şimşek, H. (2013). Sosyal Bilimlerde Nitel Araştırma Yöntemleri. Ankara: Seçkin yayıncılık.

\begin{tabular}{|c|c|}
\hline Ayşe Ŏguz ÜNVER & $\begin{array}{l}\text { Doç. Dr., Muğla Sitk1 Koçman Üniversitesi } \\
\text { Eğitim Fakültesi } \\
\text { E-mail: ayseoguz@,mu.edu.tr }\end{array}$ \\
\hline Sertaç ARABACIOĞLU & $\begin{array}{l}\text { Arş. Gör., Muğla Sitk1 Koçman Üniversitesi } \\
\text { Eğitim Fakültesi. } \\
\text { E-mail: sertacarabacioglu@mu.edu.tr }\end{array}$ \\
\hline Hasan Zühtü OKULU & $\begin{array}{l}\text { Arş. Gör., Muğla S1tk1 Koçman Üniversitesi } \\
\text { Eğitim Fakültesi } \\
\text { E-mail: hasanokulu@mu.edu.tr }\end{array}$ \\
\hline
\end{tabular}




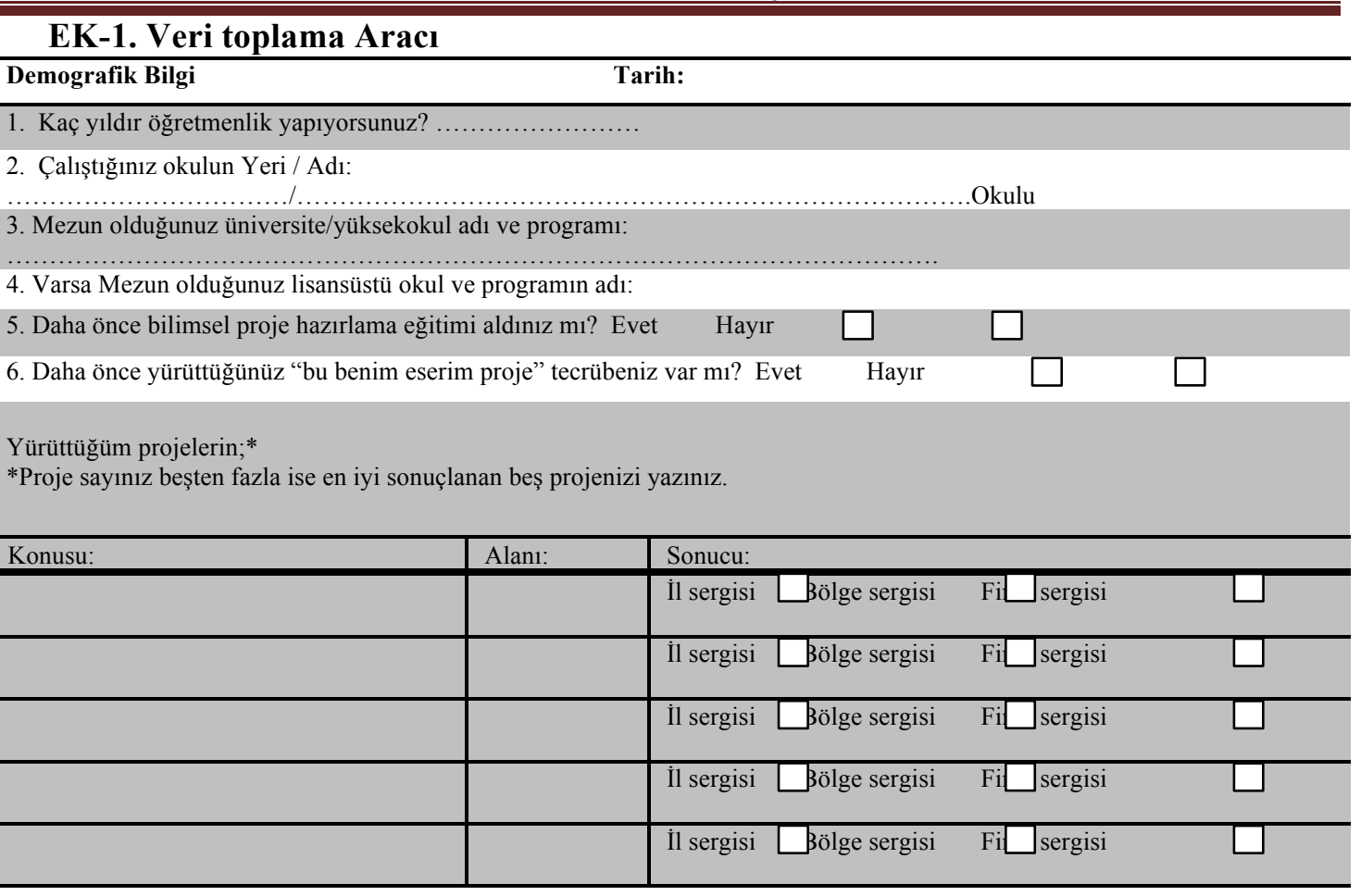

Bu alanda hazırlanacak bir eğitimden beklentileriniz:

Bu Benim Eserim yarışmasına katılımınızda karşılaştığınız zorlukları veya katıımanıza engel durumları aşağıda belirtilen maddeler için lütfen ayrı ayrı değerlendiriniz?

Bireysel açıdan:

Maddi açıdan:

Zaman açısından:

Sınıf ortamı açısından:

Öğrenci açısından:

Öğrenci velisi açısından:

Okul yönetimi açısından:

İl/İlçe Milli Eğitim Müdürlüğü açısından:

Diğer: 